\section{The American Association for Thoracic Surgery}

\section{Announcement of 2002 Annual Meeting}

$\mathrm{T}$ The Eighty-second Annual Meeting of The American Association for Thoracic Surgery will be held May 5-8, 2002, in Washington, DC, at the Washington Convention Center. The meeting of the Association is open to all physicians. House Officers and Fellows will be admitted without payment of a registration fee upon presentation of a letter from their Chief of Service either during pre-registration or at the time of registration. Nonmember physicians will be required to pay a $\$ 250$ registration fee. Members, nonmember physicians, and invited speakers will have the privilege of discussing papers.

\section{Requests for preregistration forms and hotel reservations}

Information on the 2002 Annual Meeting, including registration, hotel accommodations, and the social program, will be available in January of 2002. Requests should be forwarded directly to:

\author{
American Association for Thoracic Surgery \\ Thirteen Elm Street \\ Manchester, MA 01944 \\ (978) 526-8330; fax (978) 526-7521 \\ e-mail: aats@prri.com
}

Registration and hotel information will be available on our Web site at aats.org.

\section{Call for abstracts}

Authors submitting abstracts for the 2002 Annual Meeting must use electronic submission. Abstracts submitted electronically for consideration for presentation at the 2002 meeting must be received on or before October 19, 2001. Abstracts received after the deadline will not be considered by the Program Committee. The work must not have been presented or reported elsewhere.

\section{Electronic submission}

Deadline for submission is October 19, 2001. Please submit your abstract via the World Wide Web. All abstract submissions must be in the structured format as required by The Journal of Thoracic and Cardiovascular Surgery. The structured abstract is to contain the following major headings: Objective(s), Methods, Results, and Conclusions, and it should clearly reflect the content of the completed paper. No reference should be made on the abstract to the names or institutions of the authors.

Receipt of each abstract will be acknowledged by e-mail, fax, or mail. Notification of the decision of the Program Committee will be distributed by January 15, 2002.

Essayists selected for the program are reminded that papers presented at the meeting are to be submitted for consideration for publication to The Journal of Thoracic and Cardiovascular Surgery and must be handed to the Chair immediately prior to their presentation.

\section{Walton Lillehei Resident Forum}

The C. Walton Lillehei Resident Forum will be held on Tuesday morning, May 7, 2002. Made possible through an educational grant from St Jude Medical, The Forum will consist of the presentation of original work by residents in thoracic surgical training programs around the world. Abstracts submitted for the award should follow the guidelines of abstract submission for electronic submission noted above. The abstracts submitted for consideration for this Forum will be evaluated by the Program Committee and eight will be selected for presentation during the forum. Each of the selected authors will receive round-trip travel and accommodations for the duration of the AATS annual meeting. Additionally, one presentation will be selected by the Program Committee to receive the AATS C. Walton Lillehei Residents' Award, a \$5000 prize. Thoracic Surgery Program Directors are urged to have their residents participate in this Forum.

Abstract Deadline-Abstracts received after the deadline will not be considered

Electronic Submission Only: October 19, 2001

\section{Applications for membership}

Applications for membership in the Association must have been received by the Membership Committee Chairman no later than October 1, 2001. Applications received after that date will be deferred automatically for consideration until the 2003 meeting.

Applicants must be sponsored by three Active or Senior Members of the Association who are not members of the Membership Committee. Members should write the Chairman of the Membership Committee requesting that an application form be sent to the candidate. Requests may be sent to:

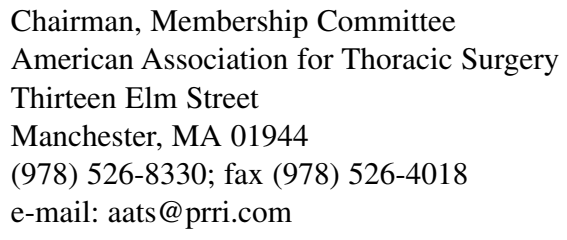

Tirone E. David, MD, Secretary 